\title{
TWENTY-SECOND ANNUAL LIST OF PAPERS
}

\author{
READ BEFORE THE AMERICAN MATHEMATICAL SOCIETY AND \\ SUBSEQUENTLY PUBLISHED, INCLUDING REFERENCES \\ TO THE PLACES OF THEIR PUBLICATION.
}

Alexander, J. W., II. See Veblen, O.

Bakmr, R. P. The Method of Monodromie with Applications to ThreeParameter Quartic Equations. Read (Chicago) April 5, 1912. Annals of Mathematics, vol. 14, No. 3, pp. 119-136; March, 1913.

Beal, F. W. Normal Congruences Determined by Centers of Geodesic Curvature. Read Sept. 12, 1911. American Journal of Mathematics, vol. 35, No. 1, pp. 10-36; Jan., 1913.

Birkнoff, Cx. D. A Determinant Formiula for the Number of Ways of Coloring a Map. Read April 27, 1912. Annals of Mathematics, vol. 14, No. 1, pp. 42-46; Sept., 1912.

- Proof of Poincaré's Geometric Theorem. Read Oct. 26, 1912. Transactions of the American Mathematical Society, vol. 14, No. 1, pp. 14-22; Jan., 1913.

— The Reducibility of Maps. Read April 27, 1912. American Journal of Mathematics, vol. 35, No. 2, pp. 115-128; April, 1913.

BuIss, G. A. Fundamental Existence Theorems. Read Dec. 28, 1907, (Chicago) Jan. 1, 1909, Sept. 15-17, 1909, Jan. 1, 1913. The Princeton Colloquium Lectures on Mathematics, pp. 1-107; New York, 1913.

BLumberg, H. Ueber algebraische Eigenschaften von linearen homogenen Differentialausdrücken. Read Sept. 10, 1912. Author's Dissertation, 53 pp.; Göttingen, 1912.

- A Set of Postulates for Arithmetic and Algebra. Read Sept. 10, 1912. Proceedings of the Fifth International Congress of Mathematicians, vol. 2 , pp. 461-465; 1913.

Bôcher, M. A Simple Proof of a Fundamental Theorem in the Theory of Integral Equations. Read Dec. 28, 1910. Annals of Mathematics, vol. 14, No. 2, pp. 84-85; Dec., 1912.

Bradshaw, J. W. An Infinite Product for $\pi / 4$ Derived from Gregory's Series. Read Sept. 7, 1910. Quarterly Journal of Pure and Applied Mathematics, vol. 43, No. 4, pp. 378-379; July, 1912.

Brenke, W. C. Transformation of Series by Means of Functions Admitting a Recurrent Relation. Read (Southwestern Section) Nov. 28, 1908, Nov. 27, 1909, and Nov. 26, 1910. Annals of Mathematics, vol. 13, No. 1, pp. 40-51; Sept., 1911.

CaJorr, F. Historical Note on the Graphic Representation of Imaginaries before the Time of Wessel. Read (Southwestern Section) Nov. 30, 1912. American Mathematical Monthly, vol. 19, Nos. 10-11, pp. 167171; Oct.-Nov., 1912.

CAmp, B. H. Singular Multiple Integrals, with Applications to Series. Read April 27, 1912. Transactions of the American Mathematical Society, vol. 14, No. 1, pp. 42-64; Jan., 1913. 
Carmichael, R. D. Note on Multiply Perfect Numbers. Read April 28, 1911. Proceedings of the Indiana Academy of Sciences, pp. 257-270; 1912.

— On the Theory of Relativity: Analysis of the Postulates. Read September 10, 1912. Physical Review, vol. 35, No. 3, pp. 153-176; Sept., 1912.

- Generalizations of Euler's $\varphi$-Function, with Applications to Abelian Groups. Read (Southwestern Section) Dec. 2, 1911. Quarterly Journal of Pure and Applied Mathematics, vol. 44, Nos. 1-2, pp. 94-104; Oct., 1912,-Jan., 1913.

- On the Remainder Term in a Certain Development of $f(a+x)$. Read Feb. 29, 1908. American Mathematical Monthly, vol. 20, No. 1, pp. 20-25; Jan., 1913.

- On the Theory of Relativity: Mass, Force and Energy; Philosophical Aspects. Read (Southwestern Section) Nov. 30, 1912. Physical Review, ser. 2, vol. 1, Nos. 2, 3, pp. 161-197; Feb.-March, 1913.

- Note on Fermat's Last Theorem. Read Dec. 31, 1912. Bulletin of the American Mathematical Society, vol. 19, No. 5, pp. 233-236, and No. 8, pp. 402-403; Feb. and May, 1913.

- Linear Mixed Equations and Their Analytic Solutions. Read Oct. 29,1910 . American Journal of Mathematics, vol. 35 , No. 2, pp. 151162; April, 1913.

- On the Theory of Linear Difference Equations. Read (Chicago) April 6, 1912. American Journal of Mathematics, vol. 35, No.2, pp. 163-182; April, 1913.

Coble, A. B. An Application of Finite Geometry to the Characteristic Theory of the Odd and Even Theta Functions. Read Feb. 24, 1912. Transactions of the American Mathematical Society, vol. 14, No. 2, pp. 241-276; April, 1913.

Cole, F. N. The Triad Systems of Thirteen Letters. Read Sept. 11, 1912. Transactions of the American Mathematical Society, vol. 14, No. 1, pp. 1-5; Jan., 1913.

Coolidge, J. I. A Study of the Circle Cross. Read Dec. 31, 1912. Transactions of the American Mathematical Society, vol. 14, No. 2, pp. 149-174; April, 1913.

Crathorne, A. R. The Total Variation in the Isoperimetric Problem with Variable End Points. Read (Chicago) March 22, 1913. Bulletin of the American Mathematical Society, vol. 19, No. 10, pp. 519-522; July, 1913.

Curtiss, D. R. An Extension of Descartes' Rule of Signs. Read (Chicago) April 8, 1910, and April 5, 1912. Mathematische Annalen, vol. 73, No. 3, pp. 424-435; March, 1913.

Dederick, L. S. On the Character of a Transformation in the Neighborhood of a Point where its Jacobian Vanishes. Read Oct. 26, 1912. Transactions of the American Mathematical Society, vol. 14, No. 1, pp. 143-148; Jan., 1913.

Denton, W. W. Projective Differential Geometry of Developable Surfaces. Read (Chicago) April 6, 1912. Transactions of the American Mathematical Society, vol. 14, No. 2, pp. 175-208; April, 1913.

Dickson, L. E. Amicable Number Triples. Read Dec.31, 1912 . American Mathematical Monthly, vol. 20, No. 3, pp. 84-92; March, 1913. 
Dines, L. L. The Highest Common Factor of a System of Polynomials in One Variable. Read April 28 and Oct. 28, 1911. American Journal of Mathematics, vol. 35, No. 2, pp. 129-150; April, 1913.

Concerning Two Recent Theorems on Implicit Functions. Read Oct. 26, 1912. Bulletin of the American Mathematical Society, vol. 19, No. 9, pp. 462-467; June, 1913.

Dopd, E. L. The Least Square Method Grounded with the Aid of an Orthogonal Transformation. Read Sept. 10, 1912. Jahresbericht der Deutschen Mathematiker-Vereinigung, vol. 21 , Nos. 8-9, pp. 177183; Aug.-Sept., 1912.

The Probability Integral Deduced by Means of Developments in Finite Form. Read Jan. 1, 1913. American Mathematical Monthly, vol. 20, No. 4, pp. 123-127; April, 1913.

The Probability of the Arithmetic Mean Compared with That of Certain Other Functions of the Measurements. Read Sept. 10, 1912. Annals of Mathematics, vol. 14, No. 4, pp. 186-198; June, 1913.

- An Erroneous Application of Bayes' Theorem to the Set of Real Numbers. Read Jan. 1, 1913. Bulletin of the American Mathematical Society, vol. 19, No. 9, pp. 479-482; June, 1913.

Eiesland, J. On a Flat Spread-Sphere Geometry in Odd Dimensional Space. Read Dec. 27, 1911. American Journal of Mathematics, vol. 35, No. 2, pp. 201-228; April, 1913.

Eisenhart, L. P. Minimal Surfaces in Euclidean Four-Space. Read Sept. 12, 1911. American Journal of Mathematics, vol. 34, No. 3, pp. 215-236; July, 1912.

- Ruled Surfaces with Isotropic Generators. Read Dec. 28, 1911. Rendiconti del Circolo Matematico di Palermo, vol. 34, No. 1, pp. 29-40; July-Aug., 1912.

Eмсн, A. On the Rectilinear Congruence Realizing a Circular Transformation of One Plane into Another. Read Sept. 12, 1911. Annals of Mathematics, vol. 13, No. 4, pp. 155-160; June, 1912.

- Involutoric Circular Transformations as a Particular Case of the Steinerian Transformation and Their Invariant Nets of Cubics. Read (Chicago) Dec. 29, 1911. Annals of Mathematics, vol. 14, No. 2, pp. 57-71; Dec., 1912.

- On Conformal Rational Transformations in a Plane. Read (Chicago) April 5, 1912. Rendiconti del Circolo Matematico di Palermo, vol. 34, No. 3, pp. 333-344; Nov.-Dec., 1912.

Fresd, P. On Coulomb's Laws of Friction. Read (Chicago) Dec. 29, 1911. Zeitschrift für Mathematik und Physik, vol. 61, Nos. 1-2, pp. 68-74; Dec., 1912.

Frizell, A. B. Foundations of Arithmetic. Read Dec. 28, 1905; (Southwestern Section) Nov. 28, 1908, (Chicago) Jan. 1, 2, 1909; (Southwestern Section) Nov. 27, 1909, Nov. 26, 1910. Kansas University Science Bulletin, vol. 5, No. 21, pp. 383-411; March, 1911.

Galajikian, H. On Certain Non-Linear Integral Equations. Read Dec. 31, 1912. Bulletin of the American Mathematical Society, vol. 19, No. 7, pp. 342-346; April, 1913.

GlenN, O. E. Theorems on Reducible Quantics. Read Sept. 6, 1910, and Dec. 27, 1911. Annals of Mathematics, vol. 14, No. 1, pp. 27-41; Sept., 1912. 
On the Structure of Forms and the Algebraical Theory of $n$ Lines. Read Feb. 26, 1910. American Journal of Mathematics, vol. 34, No. 4, pp. 449-460; Oct., 1912.

Green, G. M. Projective Differential Geometry of Triple Systems of Surfaces. Read Feb. 22, 1913. Author's Dissertation, 28 pp.; Lancaster, May, 1913.

Gronwall, T. H. On a Theorem of Fejér and an Analogon to Gibbs' Phenomenon. Read (Chicago) April 6, 1912. Transactions of the American Mathematical Society, vol. 13, No. 4, pp. 445-468; Oct., 1912.

- Sur un Théorème de M. Picard. Read (Southwestern Section) Nov. 30, 1912. Comptes Rendus de l'Académie des Sciences de Paris, vol. 155, No. 17, pp. 764-766; Oct. 21, 1912.

- On Analytic Functions of Constant Modulus on a Given Contour Read Sept. 11, 1912. Annals of Mathematics, vol. 14, No. 2, pp. 72-80; Dec., 1912.

- Ueber das Verhalten der Riemannschen Zetafunktion auf der Geraden $\sigma=1$. Read (Southwestern Section) Nov. 30, 1912. Archiv der Mathematik und Physik, ser. 3, vol. 20, No. 3, pp. 231-238; Jan., 1913.

- Some Asymptotic Expressions in the Theory of Numbers. Read (Chicago) April 6, 1912. Transactions of the American Mathematical Society, vol. 14, No. 1, pp. 113-122; Jan., 1913.

— Some Special Boundary Problems in the Theory of Harmonic Functions. Read Sept. 11, 1912. Bulletin of the American Mathematical Society, vol. 19, No. 5, pp. 227-233; Feb., 1913.

- Sur la Fonction $\zeta(s)$ de Riemann au Voisinage de $\sigma=1$. Read (Southwestern Section) Nov. 30, 1912. Rendiconti del Circolo Matematico di Palermo, vol. 35, No. 1, pp. 95-102; Jan.-Feb., 1913.

- Sur les Séries de Dirichlet Correspondant à des Caractères Complexes. Read (Southwestern Section) Nov. 30, 1912. Rendiconti del Circolo Matematico di Palermo, vol. 35, No. 2, pp. 145-159; March-April, 1913,

Hildebrand, T. H. A Contribution to the Foundations of Fréchet's Calcul Fonctionnel. Read (Chicago) April 10, 1909. American Journal of Mathematics, vol. 34, No. 3, pp. 237-290; July, 1912.

- Necessary and Sufficient Conditions for the Interchange of Limit and Summation in the Case of Sequences of Infinite Series of a Certain Type. Read (Chicago) April 6, 1912. Annals of Mathematics, vol. 14, No. 2, pp. 81-83; Dec., 1912.

Huntington, E. V. A Set of Postulates for Abstract Geometry, Expressed in Terms of the Simple Relation of Inclusion. Read Oct. 26, 1912. Mathematische Annalen, vol. 73, No. 4, pp. 522-559; May, 1913.

Hurwirz, W. A. On the Pseudo-Resolvent to the Kernel of an Integral Equation. Read Sept. 12, 1911. Transactions of the American Mathematical Society, vol. 13, No. 4, pp. 405-418; Oct., 1912.

INGoLD, L. Functional Differential Geometry. Read (Southwestern Section) Nov. 26, 1910. Transactions of the American Mathematical Society, vol. 13, No. 3, pp. 319-341; July, 1912.

JACKson, D. On the Degree of Convergence of the Development of a Continuous Function According to Legendre's Polynomials. Read Feb. 24, 1912. Transactions of the American Mathematical Society, vol. 13 , No. 3 , pp. 305-318; July, 1912. 
On Approximation by Trigonometric Sums and Polynomials. Read Feb. 24 and April 27, 1912. Transactions of the American Mathematical Society, vol. 13, No. 4, pp. 491-515; Oct., 1912.

James, G. O. Reduction of Polaris Vertical Circle Observations for Time and Azimuth. Read (Southwestern Section) Nov. 27, 1909. Popular Astronomy, vol. 18, No. 2, pp. 92-100; Feb., 1910.

On the Relation of the Inertial and Empirical Trihedrons of Gravitational Astronomy. Read (Chicago) April 5, 1912. Astronomical Journal, vol. 27, Nos. 9-10, pp. 77-82; April 20, 1912.

Karpinski, L. C. Augrim Stones. Read Sept. 11, 1912. Modern Language Notes, vol. 27, No. 7, pp. 206-209; Nov., 1912.

Hindu Numerals among the Arabs. Read Jan. 1, 1913. Bibliotheca Mathematica, ser. 3, vol. 13, No. 2, pp. 97-98; May, 1913.

The Quadripartitum Numerorum of John of Meurs. Read (Chicago) April 5, 1912; and Jan. 1, 1913. Bibliotheca Mathematica, ser. 3, vol. 13, No. 2, pp. 99-114; May, 1913.

Kasner, E. Equitangential Congruences of Curves in Space. Read Feb. 25, 1911. Rendiconti del Circolo Matematico di Palerno, vol. 35, No. 3, pp. 283-285; May-June, 1913.

Differential-Geometric Aspects of Dynamics. Read Sept. 4, 1906, Sept. 15-17, 1909, April 30, 1910, and Oct. 29, 1910. The Princeton Colloquium Lectures on Mathematics, pp. 1-117; New York, 1913.

Conformal Geometry. Read Sept. 7, 1910. Proceedings of the Fifth International Congress of Mathematicians, vol. 2, pp. 81-87; 1913.

Keyser, C. J. Concerning Multiple Interpretations of Postulate Systems and the Existence of Hyperspace. Read Jan. 1, 1913. Journal of Philosophy, Psychology and Scientific Methods, vol, 10, No. 10, pp. 253-267; May, 1913.

KILlaM, S. D. A Note on Graphical Integration of a Function of a Complex Variable. Read April 26, 1913. Bulletin of the American Mathematical Society, vol. 19, No. 10, pp. 522-524; July, 1913.

LAMOND, J. K. Improper Multiple Integrals over Iterable Fields. Read April 27, 1912. Transactions of the American Mathematical Society, vol. 13, No. 4, pp. 434-444; Oct., 1912.

Lefschetz, S. Double Curves of Surfaces Projected from Space of Four Dimensions. Read Sept. 10, 1912. Bulletin of the American Mathematical Society, vol. 19, No. 2, pp. 70-74; Nov., 1912.

Two Theorems on Conics. Read (Southwestern Section) Dec. 2, 1911. Annals of Mathematics, vol. 14, No. 2, pp. 47-50; Dec., 1912.

On the Existence of Loci with Given Singularities. Read Sept. 12, 1911. Transactions of the American Mathematical Society, vol. 14, No. 1, pp. 23-41; Jan., 1913.

- On Some Topological Properties of Plane Curves and a Theorem of Möbius. Read Sept. 12, 1911. American Journal of Mathematics, vol. 35, No. 2, pp. 189-200; April, 1913.

Lenmer, D. N. Certain Theorems in the Theory of Quadratic Residues. Read (San Francisco Section) Sept. 28, 1907. American Mathematical Monthly, vol. 20, No. 5, pp. 151-157; May, 1913.

Lennes, N. J. Concerning Van Vleck's Non-Measurable Set. Read April 27, 1912. Transactions of the American Mathematical Society, vol. 14, No. 1, pp. 109-112; Jan., 1913. 
MacGregor, H. H. Three-Dimensional Chains and the Associated Collineations in Space. Read (Chicago) Dec. 31, 1909. Annals of Mathematics, vol. 14, No. 1, pp. 1-13; Sept., 1912.

MacMillan, W. D. A Reduction of a System of Power Series to an Equivalent System of Polynomials. Read (Chicago) Dec. 29, 1910, and April 28, 1911. Mathematische Annalen, vol. 72, No. 2, pp. 157-179; May, 1912.

- A Method for Determining the Solutions of a System of Analytic Functions in the Neighborhood of a Branch Point. Read April 28, 1911. Mathematische Annalen, vol. 72, No. 2, pp. 180-202; May, 1912.

— On Poincaré's Correction to Bruns' Theorem. Read Jan. 2, 1913. Bulletin of the American Mathematical Society, vol. 19, No. 7, pp. 349355; April, 1913.

MacNeish, H. F. Linear Polars of the $k$-Hedron in $n$-Space. Read Dec. 30, 1909. Author's Dissertation, v +25 pp.; Chicago, March, 1912.

Marshatl, E. R. A Labor Saving Device for Serial Multiplication or Division by means of an Arithmometer in Cases of Small Differences of Consecutive Results. Read April 27, 1912. American Mathematical Monthly, vol. 19, Nos. 8-9, pp. 141-152; Aug.-Sept., 1912.

Miles, E. J. Determination of the Constants in Euler's Problem Concerning the Minimum Area Between a Curve and Its Evolute. Read (Chicago) Jan. 1, 1909. Annals of Mathematics, vol. 14, No. 1, pp. 14-26; Sept., 1912.

—- Surfaces of Revolution of Minimum Resistance. Read Jan. 1, 1909. Bulletin of the American Mathematical Society, vol. 19, No.1, pp.1-12; Oct., 1912.

Miller, G. A. Some Properties of the Group of Isomorphisms. Read Sept. 12, 1911. Archiv der Mathematik und Physik, ser. 3, vol. 19, No. 4, pp. 295-301; June, 1912.

— Infinite Systems of Indivisible Groups. Read (Chicago) April 5, 1912. Transactions of the American Mathematical Society, vol. 13, No. 4, pp. 419-433; Oct., 1912.

- A Few Theorems Relating to Sylow Subgroups. Read Sept. 10, 1912. Bulletin of the American Mathematical Society, vol. 19, No. 2, pp. 63-66; Nov., 1912.

_ Gauss's Lemma and Some Related Group Theory. Read (Chicago) Dec. 30, 1911. Prace Matematyczno-Fizyczne, vol. 23, pp. 25-29; 1912.

- Groups Containing a Given Number of Operators Whose Orders are Powers of the Same Prime Number. Read Dec. 28, 1911. American Journal of Mathematics, vol. 35, No. 1, pp. 1-9; Jan., 1913.

- Second Note on the Groups Generated by Operators Transforming Each Other into Their Inverses. Read Feb. 24, 1912. Quarterly Journal of Pure and Applied Mathematics, vol. 44, No. 2, pp. 142-146; Jan., 1913.

- The Product of Two or More Groups. Read Dec. 31, 1912. Bulletin of the American Mathematical Society, vol. 19, No. 6, pp. 303-310; March, 1913.

Mrtcheld, H. H. Determination of the Finite Quaternary Linear Groups. Read Oct. 28, 1911, and Feb. 24, 1912. Transactions of the American Mathematical Society, vol. 14, No. 1, pp. 123-142; Jan., 1913. 
Moore, C. L. E. See Phillips, H. B.

Moone, C. N. On Convergence Factors in Double Series and the Double Fourier Series. Read April 29 and Dec. 27, 1911. Transactions of the American Mathematical Society, vol. 14, No. 1, pp. 73-104; Jan., 1913.

Moore, R. L. On Duhamel's Theorem. Read (Chicago) April 9, 1910. Annals of Mathematics, vol. 13, No. 4, pp. 161-166; June, 1912.

Moulton, F. R. Closed Orbits of Ejection and Related Periodic Orbits. Painlevé's Theorem. Read (Chicago) April 6, 1912. Proceedings of the London Mathematical Society, ser. 2, vol. 11, Nos. 4-5, pp. 367397; Oct., 1912.

— Periodic Oscillating Satellites in the Problem of Three Bodies. Read (Chicago) April 10, 1909. Mathematische Annalen, vol. 73, No. 4, pp. 441-479; May, 1913.

— Relations among Families of Periodic Orbits in the Restricted Problem of Three Bodies. Read (Chicago) Dec. 29, 1911. Proceedings of the Fifth International Congress of Mathematicians, vol. 2, pp. 182-187; 1913.

Newson, H. B. Theory of Collineations. Read (Southwestern Section) Dec. 1, 1906, Nov. 30, 1907; Sept. 11, 1908, Sept. 14, 1909; (Southwestern Section) Nov. 27, 1909. Kansas University Science Bulletin, vol. 6, No. 1, pp. 1-319; Dec., 1911.

OsGood, W. F. Existenzbeweis betreffend Funktionen, welche zu einer eigentlich diskontinuierlichen automorphen Gruppe gehören. Read Oct. 26, 1912. Rendiconti del Circolo Matematico di Palermo, vol. 35, No. 1, pp. 103-106; Jan.-Feb., 1913.

Osgood, W. F., and TAYLOR, E. H. Conformal Transformations on the Boundaries of Their Regions of Definition. Read Dec. 30, 1902, and April 30, 1910. Transactions of the American Mathematical Society, vol. 14, No. 2, pp. 277-298; April, 1913.

Phillips, H. B., and Moore, C. L. E. A Theory of Linear Distance and Angle. Read April 27, 1912. Proceedings of the American Academy of Arts and Sciences, vol. 48, No. 3, pp. 45-80; July, 1912.

Pitcher, A. D. Concerning the Property $\Delta$ of a Class of Functions. Read April 26, 1913. Bulletin of the American Mathematical Society, vol. 19, No. 9, pp. 468-472; June, 1913.

Ranum, A. On the Projective Differential Geometry of $n$-Dimensional Spreads Generated by $\infty^{1}$ Flats. Read Sept. 12 and Dec. 27, 1911. Annali di Matematica Pura ed Applicata, ser. 3, vol. 19, No. 3, pp. 205-249; Sept., 1912.

- Lobachefskian Polygons Trigonometrically Equivalent to the Triangle. Read Sept. 10, 1912. Jahresbericht der Deutschen MathematikerVereinigung, vol. 21, Nos. 10-12, pp. 228-240; Oct.-Dec., 1912.

ReDdick, H. W. Systems of Plane Curves Whose Intrinsic Equations are Analogous to the Intrinsic Equation of an Isothermal System. Read Oct. 26, 1912. Annals of Mathematics, vol. 14, No. 4, pp. 179185; June, 1913.

Richardson, R. G. D. Ueber die notwendigen und hinreichenden Bedingungen für das Bestehen eines Kleinschen Oszillationstheorems. Read Dec. 28, 1911. Mathematische Annalen, vol. 73, No. 2, pp. 289-304; Jan., 1913. 
Rowver, W. H. The Southerly and Easterly Deviations of Falling Bodies for an Unsymmetrical Gravitational Field of Force. Read (Southwestern Section) Dec. 2, 1911, and (Chicago) April 5, 1912. Transactions of the American Mathematical Society, vol. 13, No. 4, pp. 469490; Oct., 1912.

Rowe, J. E. Bicombinants of the Rational Plane Quartic and Combinants of the Rational Plane Quintic. Read Sept. 12, 1911. Transactions of the American Mathematical Society, vol. 13, No. 3, pp. 387404; July, 1912.

Three or More Rational Curves Collinearly Related. Read Dec. 31, 1912. Bulletin of the American Mathematical Society, vol. 19, No. 8, pp. 395-401; May, 1913.

- Cusp and Undulation Invariants of Rational Curves. Read Feb. 24, 1912. Annals of Mathematics, vol. 14, No. 4, pp. 199-210; June, 1913.

RuNGE, C. Graphische Lösung von Randwertaufgaben der Gleichung $\partial^{2} u / \partial x^{2}+\partial^{2} u / \partial y^{2}=0$. Read Oct. 30, 1909. Göttinger Nachrichten, 1911, pp. 443-448.

Schweitzer, A. R. Theorems on Functional Equations. Read April 27, 1912. Bulletin of the American Mathematical Society, vol. 19, No. 2, pp. 66-70; Nov., 1912.

- A Theory of Geometrical Relations. Read Sept. 3, 1906, and (Chicago) March 30, 1907. American Journal of Mathematics, vol. 35, No. 1, pp. 37-56; Jan., 1913.

SHaw, J. B. Quaternion Developments with Applications. Read (Chicago) April 8, 1910, and April 28, 1911. Transactions of the American Mathemalical Society, vol. 13, No. 3, pp. 279-292; July, 1912.

Siceloff, L. P. Simple Groups from Order 2001 to Order 3640. Read Oct. 28, 1911. American Journal of Mathematics, vol. 34, No. 4, pp. 361-372; Oct., 1912.

Silnerman, L. L. On the Definition of the Sum of a Divergent Series. Read Oct. 29, 1910, Dec. 28, 1911, and Jan. 2, 1913. University of Missouri Studies, Mathematics Series, vol. 1, No. 1, pp. 1-96; April, 1913.

Slocum, S. E. A General Formula for the Torsional Deflection of Shafts. Read Dec. 28, 1911. Journal of the Franklin Institute, vol. 174, No. 1, pp. 83-89; July, 1912.

SmaIL, L. L. Some Generalizations in the Theory of Summable Divergent Series. Read Jan. 2, 1913. Author's Dissertation, 46 pp.; Lancaster, May, 1913.

Snyder, V. Algebraic Surfaces Invariant under an Infinite Discontinuous Group of Birational Transformations. Second Paper. Read Jan. 2, 1913. Transactions of the American Mathematical Society, vol. 14, No. 1, pp. 105-108; Jan., 1913.

Stouffer, E. B. Invariants of Linear Differential Equations with Applications to Ruled Surfaces in Five-Dimensional Space. Read April 29, 1911. Proceedings of the London Mathematical Society, ser. 2, vol. 11, No. 3, pp. 185-224; July, 1912.

TAylor, F. H. An Extension of a Theorem of Painlevé. Read Oct. 26, 1912. Bulletin of the American Mathematical Society, vol. 19, No. 8, pp. 403-406; May, 1913.

— See Osgood, W. F. 
Vandiver, H. S. Theory of Finite Algebras. Read (Chicago) Dec. 29, 1911. Transactions of the American Mathematical Society, vol. 13, No. 3, pp. 293-304; July, 1912.

VAN VleCK, E. B. On the Extension of a Theorem of Poincare for Difference Equations. Read April 29, 1911. Transactions of the American Mathematical Society, vol. 13, No. 3, pp. 342-352; July, 1912.

- One-Parameter Projective Groups and the Classification of Collineations. Read April 29, 1911. Transactions of the American Mathematical Society, vol. 13, No. 3, pp. 353-386; July, 1912.

Veblen, O. An Application of Modular Equations in Analysis Situs. Read April 27, 1912. Annals of Mathematics, vol. 14, No. 2, pp. 86-94; Dec., 1912.

- Decomposition of an $n$-Space by a Polyhedron. Read Sept. 11, 1912. Transactions of the American Mathematical Sociely, vol. 14, No. 1, pp. 65-72; Jan., 1913.

Veblen, O., and Alexander, J. W., II. Manifolds of $n$ Dimensions. Read Feb. 22, 1913. Annals of Mathematics, vol. 14, No. 4, pp. 163178; June, 1913.

White, H. S. Triple Systems as Transformations, and Their Paths among Triads. Read Sept. 11, 1912. Transactions of the American Mathematical Society, vol. 14, No. 1, pp. 6-13; Jan., 1913.

Wilczynski, E. J. A Forgotten Theorem of Newton on Planetary Motion and an Instrumental Solution of Kepler's Problem. Read (Chicago) April 5, 1912. Astronomical Journal, vol. 27, No. 20, pp. 155-156; Jan. 31, 1913.

Williams, F. B. Curves on Quintic Scrolls. Read (Chicago) Dec. 30, 1910. American Journal of Mathematics, vol. 34, No. 4, pp. 421-448; Oct., 1912.

Williams, K. P. The Solutions of Non-Homogeneous Linear Difference Equations and Their Asymptotic Form. Read Feb. 24, 1912. Transactions of the American Mathematical Society, vol. 14, No. 2, pp. 209240; April, 1913.

- The Asymptotic Form of the Function $\Psi(x)$. Read April 26, 1913. Bulletin of the American Mathematical Society, vol. 19, No. 9, pp. 472479; June, 1913.

Wilson, E. B. Some Mathematical Aspects of Relativity. Read Dec. 27, 1911. Proceedings of the American Academy of Arts and Sciences, vol. 48, No. 11, pp. 389-507; Nov., 1912.

Young, A. E. On Certain Orthogonal Systems of Lines and the Problem of Determining Surfaces Referred to Them. Read April 28, 1911. American Journal of Mathematics, vol. 34, No. 4, pp. 373-382; Oct., 1912. 